\title{
Effects of di-n-butyl phthalate on the physiology and ultrastructure of cucumber seedling roots
}

\author{
Ying Zhang • Yue Tao • Guoqiang Sun • Lei Wang
}

Received: 2 December 2013 / Accepted: 20 January 2014 / Published online: 28 February 2014

(C) The Author(s) 2014. This article is published with open access at Springerlink.com

\begin{abstract}
Agricultural pollution caused by the use of plastic sheetings has been documented to be a widespread problem in most of the major crop-planting regions of the world. In order to better understand the phytotoxic mechanisms induced by phthalic acid esters involved with this problem, Cucumber sativus L. cv Jinyan No. 4 were sown in pots to the three-leafstage in the presence of di- $n$-butyl phthalate (DBP; $0,30,50$, 100 , and $200 \mathrm{mg} \mathrm{L}^{-1}$ ) for 1,3 , 5, or 7 days. Physiology, biochemistry, and ultrastructure of seedling roots were examined. The results indicated that activities of three antioxidant enzymes (superoxide dismutase (SOD), catalase (CAT), and peroxidase (POD)) were stimulated at low-DBP treatments and decreased under higher levels $\left(>100 \mathrm{mg} \mathrm{L}^{-1}\right)$ compared to the controls. On the other hand, SOD and POD provided a better defense against DBP-induced oxidative damage in the roots of cucumber seeding, compared to CAT. The productions of both malondialdehyde (MDA) and proline (Pro) were promoted under DBP stress. Visible impact on the cytoderm, mitochondrion, and vacuole was detected, possibly as a consequence of free radical generation. These results suggested that activation of the antioxidant system by DBP led to the formation of reactive oxygen species that resulted in cellular damage.
\end{abstract}

Keywords DBP · Antioxidant enzymes $\cdot$ Cucumber . Ultrastructure

Responsible editor: Elena Maestri

Y. Zhang $(\bowtie) \cdot$ Y. Tao $\cdot$ G. Sun $\cdot$ L. Wang

School of Resource and Environment, Northeast Agricultural

University, Harbin 150030, People's Republic of China

e-mail: zhangyinghr@hotmail.com

Y. Tao

e-mail: 782873201@qq.com

$\begin{array}{ll}\text { Abbreviations } \\ \text { CAT } & \text { catalase } \\ \text { DBP } & \text { di- } n \text {-butyl phthalate } \\ \text { PAEs } & \text { phthalic acid esters } \\ \text { PBS } & \text { phosphate-buffered saline solution } \\ \text { POD } & \text { peroxidase } \\ \text { Pro } & \text { proline } \\ \text { MDA } & \text { malondialdehyde } \\ \text { ROS } & \text { reactive oxygen species } \\ \text { SOD } & \text { superoxide dismutase }\end{array}$

\section{Introduction}

Phthalic acid esters (PAEs) are mainly used in the plastics industry as adhesives and plasticizers for polyvinyl chloride materials to improve flexibility and easy manufacturing. They are a kind of toxic persistent organic pollutants (Clausen et al. 2004; Gomez-Hens and Aguilar-Caballos 2003a, b; Wensing et al. 2005). They have been found in many environmental samples, such as water, soil (Liang et al. 2010), sediments (Waters et al. 2007), and atmosphere (Zeng et al. 2009; Wang et al. 2012), and even in tissues of higher animals (Russo et al. 2012). Release of PAEs into the environment during manufacture, use, and disposal has caused increasing attention, because some PAEs, as well as their metabolites and degradation products, have been reported to cause adverse effect on health, such as endocrine disruption, hypospadias, reproductive toxicity, malformations, and fatality (Gomez-Hens and Aguilar-Caballos 2003a, b; Inoue et al. 2005; Koch et al. 2005; Sathyanarayana et al. 2008).

In China, there is an extensive use and continuous exploitation of plastic sheeting as agricultural films in most farmlands, in order to yield more farm produce (Wang et al. 2012). Consequently, large amounts of PAE compounds from the plastic films caused a serious threat to agricultural 
environment (Fromme et al. 2004; Wang et al. 2013; Xu et al. 2008; Kong et al. 2012). di- $n$-butyl phthalate (DBP), one of the important members in the family of PAEs was listed as environmental priority pollutants by the US Environmental Protection Agency (1991), the European Union (1993), and China National Environmental Monitoring Center (Wang et al. 1995). DBP pollutants can enter soils via irrigation and the application of pesticides and plastic film (Michael et al. 1984). As a result, the decrease in the quality of vegetables caused by DBP pollution has posed a potential risk for human health through the food chain. Previous studies have shown that many pollutants are redox-active (Kang et al. 2007; Kreiner et al. 2002). The redox products could attack the cell membrane bringing about oxidative stress to the body and even causing cell death or canceration (Zhang et al. 2003). However, organisms were not attacked in a passive state during the process of the reaction of lipid peroxidation owing to active oxygen free radicals; there was a well-established antioxidant system in their body. For instance, SOD, CAT, and POD are three of the most important antioxidant enzymes, Pro and MDA are two of the antioxidating non-enzyme substances. Enzymatic and non-enzymatic reactions play an important role in removing toxic substances which are generated by chemical mutagen, promote cancer agent, and DNA hydrogen peroxide in normal cells.

Recently, many studies on PAES oxidative effects were mainly focused on various animal and plants cells. However, the biological effects of PAEs on early growth stages of vegetable crops have not been widely investigated until now and only few studies were conducted about the changes in physiology and ultrastructure of plants under PAE stress. Plant roots as a media of absorption and transportation of nutrients have an important effect to plant growth. To investigate the effects of PAEs on plant roots has a profound significance. Cucumber as one of the public favorite vegetables has been selected as a model plant in many studies (Huang et al. 2009). In China, cucumber is usually cultivated in greenhouse, and in a continuous cropping system. Due to the extensive use of plastic films as mulching materials, cucumber was seriously affected by the pollution of PAEs. In this paper, the changes of antioxidant defense system and cell ultrastructure of cucumber seedling roots under DBP stress were investigated. The toxic effect of DBP on the roots of cucumber seedling was analyzed.

\section{Materials and methods}

Plant materials and stress treatment

Seeds of Cucumber sativus L. cv Jinyan No. 4 were planted into planting pots in September at Northeast Agricultural University horticultural garden. The average temperature in the greenhouse was $27 \pm 1^{\circ} \mathrm{C}$ during the day and was $20 \pm 1^{\circ} \mathrm{C}$ during the night. The relative humidity was kept at 60-70\%. For DBP treatment and cucumber plants were applied according to the method of Zhang et al. (2014).

Activities of antioxidant enzymes

Root tissues $(0.5 \mathrm{~g})$ were ground to fine powder using a chilled pestle and mortar. Five milliliters of $50 \mathrm{mM}$ potassium phosphate buffer ( $\mathrm{pH} 7.0$ ), $0.2 \mathrm{mM}$ ethylenediamine tetraacetic acid, $1 \mathrm{mM}$ ascorbic acid, and $2 \%(w / v)$ polyvinylpyrrolidone were added to the powder. The homogenate was centrifuged at $12,000 \times g$ for $20 \mathrm{~min}$ at $4{ }^{\circ} \mathrm{C}$ and the supernatant was collected for assays of the activity of enzymes.

The CAT (EC 1.11.1.6) activity was determined by measuring the rate of $\mathrm{H}_{2} \mathrm{O}_{2}$ consumption at $240 \mathrm{~nm}$ (Aebi 1984). The reaction mixture contained $50 \mathrm{mM}$ potassium phosphate buffer ( $\mathrm{pH} 7.0$ ), $10.5 \mathrm{mM} \mathrm{H}_{2} \mathrm{O}_{2}$, and $0.2 \mathrm{ml}$ enzyme fraction.

The POD (EC 1.11.1.7) activity was measured based on the method of Pinhero et al. (1997). The reaction mixture contained $50 \mathrm{mM}$ phosphate buffer (pH 7.8), $200 \mathrm{mM}$ $\mathrm{H}_{2} \mathrm{O}_{2}, 25 \mathrm{mM}$ guaiacol, and $0.2 \mathrm{ml}$ of the supernatant. The molar extinction coefficient of $26.6 \mathrm{mM}^{-1} \mathrm{~cm}^{-1}$ was used for the enzyme activity calculation. Enzyme activity was defined by the absorbance at $470 \mathrm{~nm}$ changes per minute.

The SOD (EC 1.15.1.1) activity was determined by the method of Giannopolitis and Reis (1977). The reaction mixture was prepared by mixing $50 \mathrm{mM}$ phosphate buffer ( $\mathrm{pH} 7.8), 77.12 \mu \mathrm{M}$ nitro blue tetrazolium, 0.1 M EDTA, $13.37 \mathrm{mM}$ methionine, $0.1 \mathrm{ml}$ enzyme fraction, and $20 \mu \mathrm{M}$ riboflavin. The mixture was illuminated for $10 \mathrm{~min}$ in an aluminum foil-lined box, containing two $20 \mathrm{~W}$ fluorescent tubes. A control tube in which the sample was unirradiated was run in parallel. The solution absorbance at $560 \mathrm{~nm}$ was recorded using a spectrophotometer. Fifty percent inhibition rate of nitro blue tetrazolium was taken as equivalent to 1 unit of SOD activity.

\section{Antioxidation non-enzyme substrate assay}

The content of MDA was measured according to the method of Chen et al. (2013). About $0.5 \mathrm{~g}$ fresh root samples were submerged in $5.0 \mathrm{ml}$ of $5 \%(w / v)$ trichloroacetic acid in boiling water bath for $10 \mathrm{~min}$ and then centrifuged at $12,000 \times \mathrm{g}$ for $10 \mathrm{~min}$. The supernatant was measured at the absorbance of 532, 600, and $450 \mathrm{~nm}$.

The Pro content was determined according to the method described by Shevyakova et al. (2009). Root samples (0.5 g) were homogenized in $5 \mathrm{ml}$ of $3 \%(w / v)$ sulfosalicylic acid and put in boiling water bath for $10 \mathrm{~min}$, then filtered into a clean test tube after cooling. Two milliliters filtrate was taken to mix with $2 \mathrm{ml}$ acetic acid and $2 \mathrm{ml}$ of $2.5 \%(w / v)$ acidic ninhydrin for another $30 \mathrm{~min}$, in boiling water bath. Five milliliters 
toluene was added in the mixture, and then the whole composition was shaken for $30 \mathrm{~s}$. The extract was measured at the absorbance of $520 \mathrm{~nm}$.

\section{Observations of root ultrastructure}

Two roots from each treatment were randomly selected. Small root fragments (about $1 \mathrm{~mm}^{2}$ in length) were fixed in $2.5 \%(\mathrm{v} /$ v) glutaraldehyde $(\mathrm{pH} 7.2)$ at $4{ }^{\circ} \mathrm{C}$ overnight. The samples were washed three times by phosphate-buffered saline solution (PBS) (pH 6.8), and immersed in $2 \%(\mathrm{~m} / \mathrm{v})$ osmium tetroxide solution for $4 \mathrm{~h}$ in a hood. Subsequently, PBS (pH 6.8) and different concentrations of ethanol solutions were used to rinse and dehydrate the sample. Ethanol was replaced by acetone solution twice. Finally, the specimens were embedded in Spurr's resin, and polymerized at $60{ }^{\circ} \mathrm{C}$. Ultra-thin sections $(80 \mathrm{~nm})$ were collected on copper grids (300 meshes) and double stained with $1.0 \%(w / v)$ uranyl acetate followed by $5.0 \%(w / v)$ lead citrate. Samples were observed at $90 \mathrm{kV}$ using an $\mathrm{H}-600 \mathrm{IV}$ transmission electron microscope (Hitachi, Tokyo, Japan).

\section{Statistical analyses}

To test the effects of PAE stress on the activity of enzymes, and the antioxidation non-enzyme substrate contents, a completely random experimental design was adopted. All the experimental data were expressed with five replicates. Data were analyzed by one-way analysis of variance. Mean values were compared by Duncan's new multiple range test at the $5 \%$ level using the SPSS 19.0 software. The data were represented as mean $\pm \mathrm{SD}$.

\section{Result}

The activities of SOD, CAT, and POD in the roots of cucumber seedling varied with different concentrations of DBP and treatment time. The results indicated that compared to the control group, both SOD (Fig. 1) and POD (Fig. 3) activities increased significantly $(p<0.05)$ during whole treatment at all DBP concentrations. The highest activity of SOD and CAT was observed at 5 and 3 days (Fig. 2), respectively, afterwards decrease in activity was observed for the two enzymes after 5 and 7 days, respectively. The results indicated that two antioxidant enzymes' activities showed an increase at lower DBP concentration and a decline under higher DBP concentration. Application of $50 \mathrm{mg} \mathrm{L}^{-1}$ DBP concentration led to a significant increase in activities of antioxidant enzymes (SOD and CAT). The CAT activity was found to be inhibited significantly $(P<0.05)$ when exposed to 100 and $200 \mathrm{mg} \mathrm{L}^{-1} \mathrm{DBP}$ at 7 days; but inhibition was more severe at $200 \mathrm{mg} \mathrm{L}^{-1} \mathrm{DBP}$ application. In contrast, the activities of POD increased progressively during the treatment period (1-7 days) compared to that in the roots of plants not exposed to DBP (Fig. 3).

The effect of DBP stress on the content of MDA in the roots of cucumber is shown in Fig. 4. The result showed that the content of MDA in roots was enhanced with the extension in time of DBP treatment. The increase was more pronounced with increasing stress by DBP. Compared with the controls, the maximum MDA contents were found at $200 \mathrm{mg} \mathrm{L}^{-1} \mathrm{DBP}$ on the seventh day. DBP at $200 \mathrm{mg} \mathrm{L}^{-1}$ resulted in 2.31 times increase in MDA content in comparison to the control. A similar increasing effect of DBP treatment was also found in Pro content (Fig. 5). The content of Pro was significantly enhanced about 4.99 times compared with the control, under $200 \mathrm{mg} \mathrm{L}^{-1}$ DBP treatment.

Ultrastructural micrographs of cucumber root showed the typical cellular ultrastructure of root cells with or without DBP (Fig.6, a-e). In well-defined cellular organelles, the cell walls were closely linked. The mitochondria of control plants exhibited an integrated structure. The endoplasmic reticulum and golgi apparatus were clearly visible. Starch grains displayed a spherical shape. Compared with untreated seedlings, the effect of DBP stress on the ultrastructure was much. Root cells became deteriorated, swollen vesicles appeared, endoplasmic reticulum became blurred, and the number of golgi apparatus decreased. Specifically, the mitochondria gradually swelled and inner cristae became invisible under DBP stress. Inner cristae in mitochondria even disintegrated eventually in some cells. Plasmolysis was observed in some cells and the plasma membrane had ruptured. Moreover, compared with control, a great number of starch grains were detected within the cells.

\section{Discussion}

Normally, reactive oxygen species (ROS) levels are in a dynamic balance with the antioxidant enzyme level. However, if the free radicals induced directly or indirectly by xenobiotic pollutants were accumulated in the body, the natural antioxidant defenses could be damaged. The superfluous ROS could result in severe sub-cellular injuries (Nel et al. 2006). The enzymes SOD, CAT, and POD, and nonenzymatic substances such as MDA and Pro were reported to be involved in the detoxification of $\mathrm{O}_{2}^{-}$. (SOD) and $\mathrm{H}_{2} \mathrm{O}_{2}$ (CAT, POD), and prevented the formation of ROS (Wen et al. 2011).

SOD was the first enzyme in the detoxifying process that converts $\mathrm{O}_{2}^{-}$. radicals to $\mathrm{H}_{2} \mathrm{O}_{2}$ at a very rapid rate (Hasan et al. 2009). According to the current study, SOD activities presented a first rising then falling trend. It might be due to increase in production of superoxide which leads to increase in genes encoding SOD, under the stress of DBP (Mishra et al. 2006a, b; Zhang et al. 2009). That excessive ROS produced 
Fig. 1 The effect of DBP on the SOD activity of $C$. sativus $\mathrm{L}$. cv Jinyan No. 4

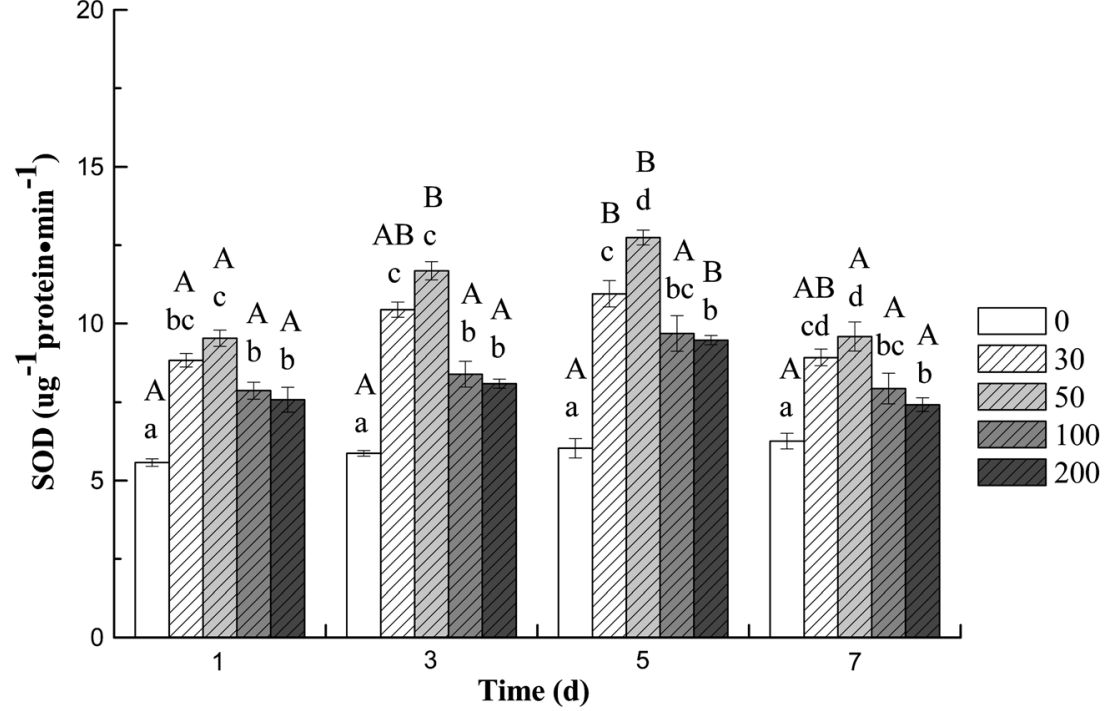

along with the extension of processing time could decline the SOD activities (CHO and SEO 2005). If ROS generation exceeded the elimination ability of antioxidant enzymes, activities of antioxidant enzymes in plants were decreased ( $\mathrm{Li}$ et al. 2011). The major function of CAT was documented to metabolize the peroxide liberated in the peroxisome following the conversion of glycolate during photorespiration (Qureshi et al. 2007). We noticed that with the extension of exposure time and increasing concentration of DBP, CAT activities of cucumber seedling showed more obvious decrease than that of SOD and POD, which might be due to the accumulation of $\mathrm{H}_{2} \mathrm{O}_{2}$, the product of free radical could restrained the activity of fermentation. Previous observations have proved that PAEs could overproduce $\mathrm{H}_{2} \mathrm{O}_{2}$ (Zhang et al. 2014; Bai et al. 2009). Moreover, the formation of $\mathrm{H}_{2} \mathrm{O}_{2}$ was also detected under the impact of other pollutants (Sanchez-Moreiras and Reigosa 2005; Li et al. 2013; Choudhary et al. 2012).
POD was known to play an important role in oxidative stress conditions. Induction of POD activity was documented under many stress conditions such as high temperature, $\mathrm{NaCl}$ stress, and toxic concentrations of $\mathrm{Pb}, \mathrm{Zn}, \mathrm{Cu}$, and $\mathrm{Cd}$ (Radotic et al. 2000a, b). In the present investigation, enhancement in POD activity was observed due to the duration of pollutant stress, which was in agreement with the early findings of Odjegba and Fasidi (2007). The phenomenon could be speculated by the fact that under DBP stress, production of POD increased, and existing enzyme pools were activated or expression of genes encoding POD was increased.

Meanwhile, activities of SOD, CAT, and POD in roots continuously increased within the roots and indicated that the cucumber could resist lower-concentration DBP stress ( $<50 \mathrm{mg} \mathrm{L}^{-1}$ ) by activating the antioxidant defense system. The findings suggested that the antioxidant defense system in roots eliminated ROS efficiently at low-concentration DBP, and
Fig. 2 The effect of DBP on the CAT activity of $C$. sativus $\mathrm{L}$. cv Jinyan No. 4

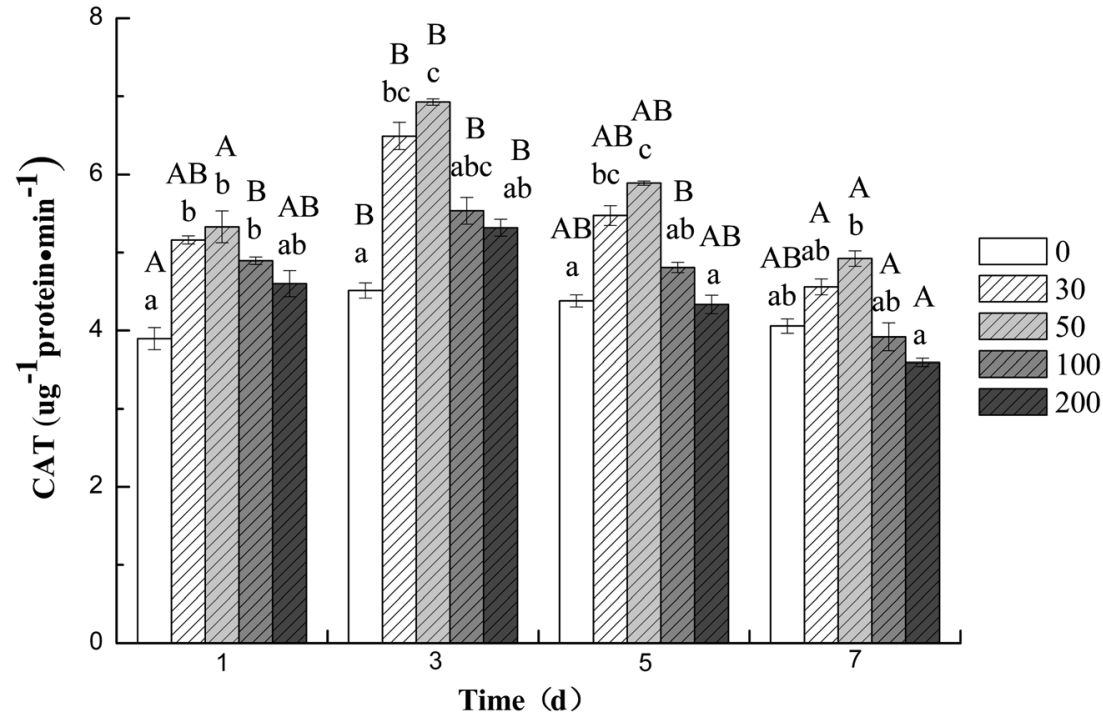


Fig. 3 The effect of DBP on the POD activity of $C$. sativus L. cv Jinyan No. 4

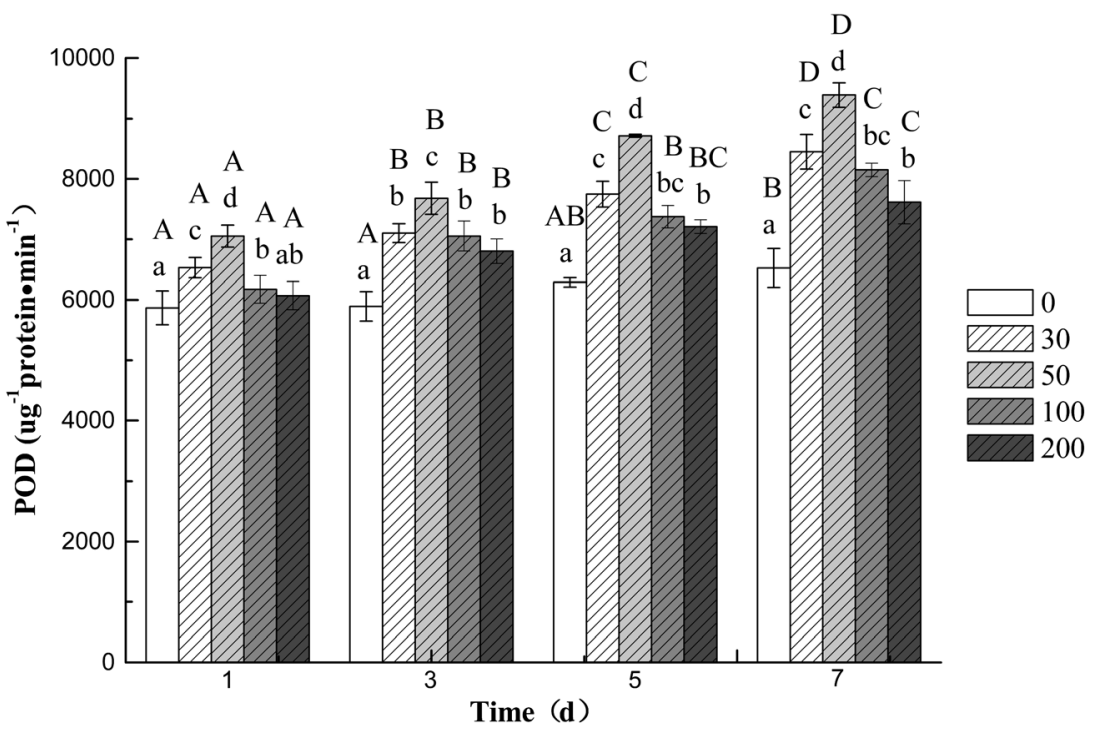

provided protection from oxidative stress. This observation was consistent with that obtained with the leaves of cucumber seedling treated with DEP (Zhang et al. 2014). Qu's research also got the same conclusion ( $\mathrm{Qu}$ et al. 2010). In their study, the toxic effects of different concentrations $(0.1-200 \mathrm{mg} / \mathrm{L})$ of perfluorooctane sulfonate on wheat were investigated. Their results showed that low concentrations of perfluorooctane sulfonate $\left(0.1-10 \mathrm{mg} \mathrm{L}^{-1}\right)$ induced SOD and POD activities in wheat roots and leaves, a high concentration of perfluorooctane sulfonate $\left(200 \mathrm{mg} \mathrm{L}^{-1}\right)$ inhibited the activities of SOD and POD.

In this study, CAT activity in roots decreased at the high concentrations of DBP along with time. It indicated that ROS elimination of CAT was limited. DBP could induce higher SOD and POD activities than CAT activity. The result suggested that SOD and POD exhibited a better defense mechanism against DBP-induced oxidative damage in the roots of cucumber seeding.
The imbalance between ROS generation and removal results in damage to DNA, lipids, and proteins (Valko et al. 2006). Lipid peroxidation of polyunsaturated fatty acids is initiated due to the formation of ROS resulting in reactive carbonyl compounds production. MDA is among secondary products of lipid peroxidation and is extensively studied as a potential biomarker for oxidative stress (Nielsen et al. 1997). MDA concentration has been measured to examine oxidative stress and as an indicator of oxidative imbalance during the onset of many diseases (Niki 2008). As depicted in Fig. 2 the MDA content changed slightly during exposure. With increased concentration of DBP and exposure duration, the MDA content increased significantly. These results also indicated that DBP resulted in an increase of ROS. ROS, in turn, stimulated the response of antioxidant defenses and resulted in a decreased in SOD, CAT, and POD activities. Demiral and
Fig. 4 The effect of DBP on the MDA content of $C$. sativus L. cv Jinyan No. 4

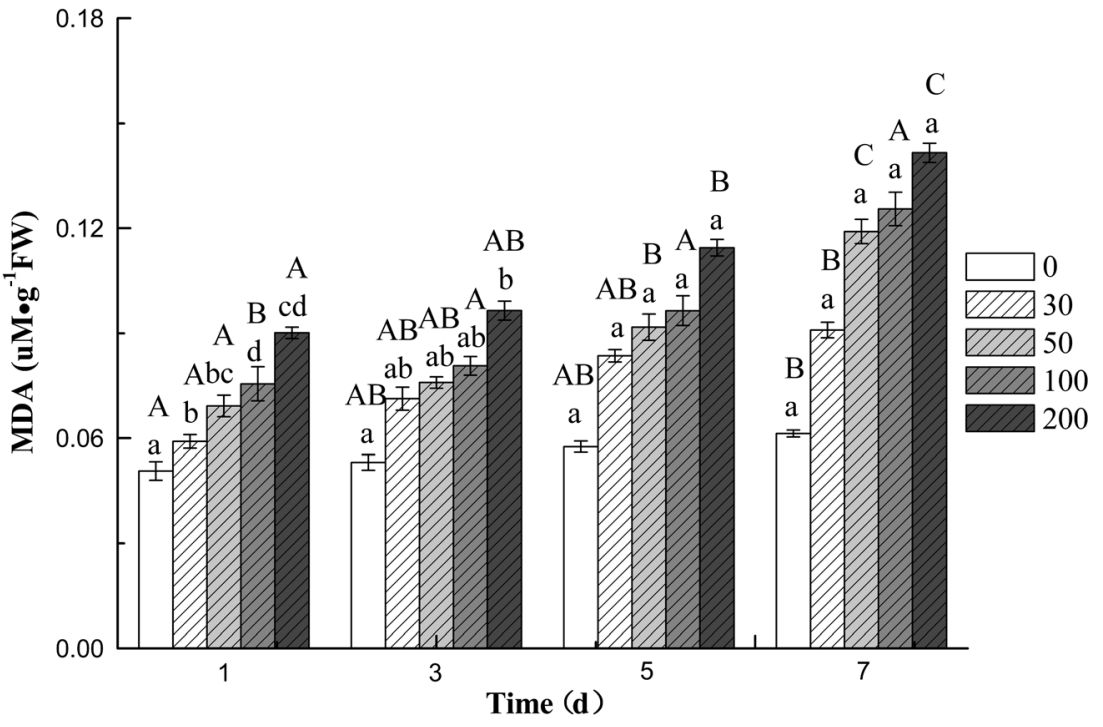


Fig. 5 The effect of DBP on the Pro content of C. sativus L. cv Jinyan No. 4

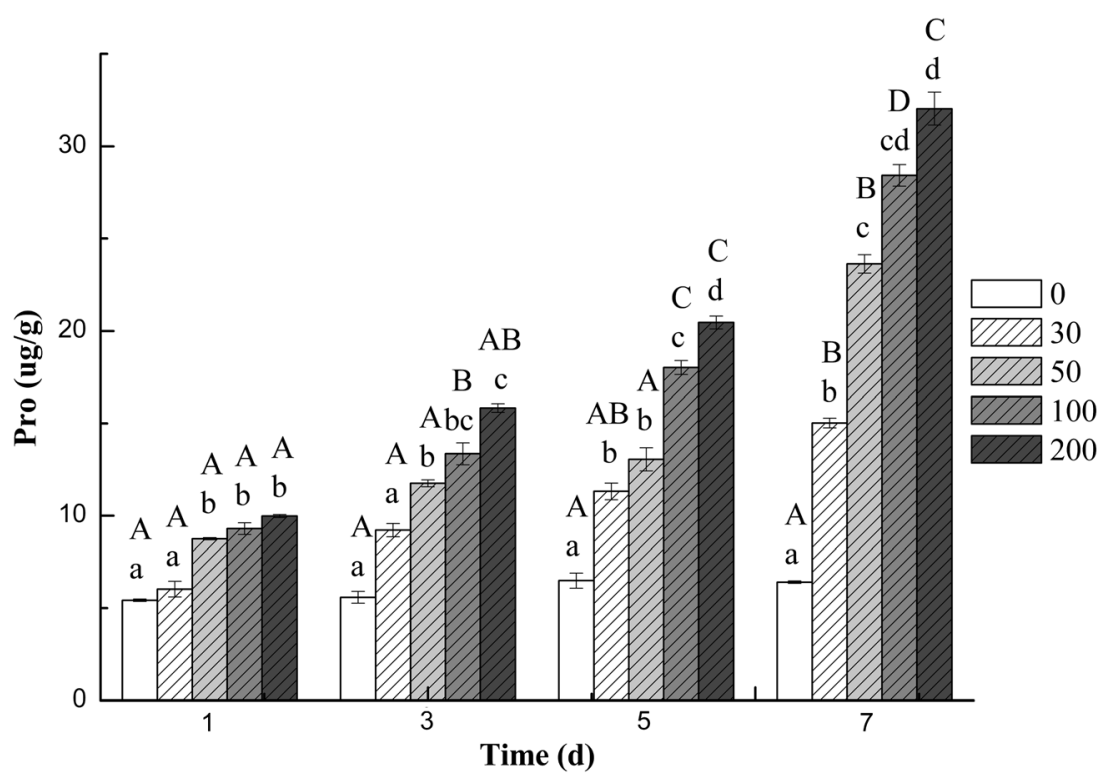

Türkan (2005) reported that slight decline of SOD and CAT activity was found in roots of IR-28 under increased salt concentrations, respectively. The changes in the MDA contents were approximately same as those observed by Bai et al. (2009) and Liu et al. (2012b).
Pro was generally assumed to serve as a physiologically compatible solute that increases as needed to maintain a favorable osmotic potential between the cell and its surroundings (Pollard and Wyn Jones 1979). The Pro contents in roots had the same trend to MDA. In salt-tolerant and relatively salt-
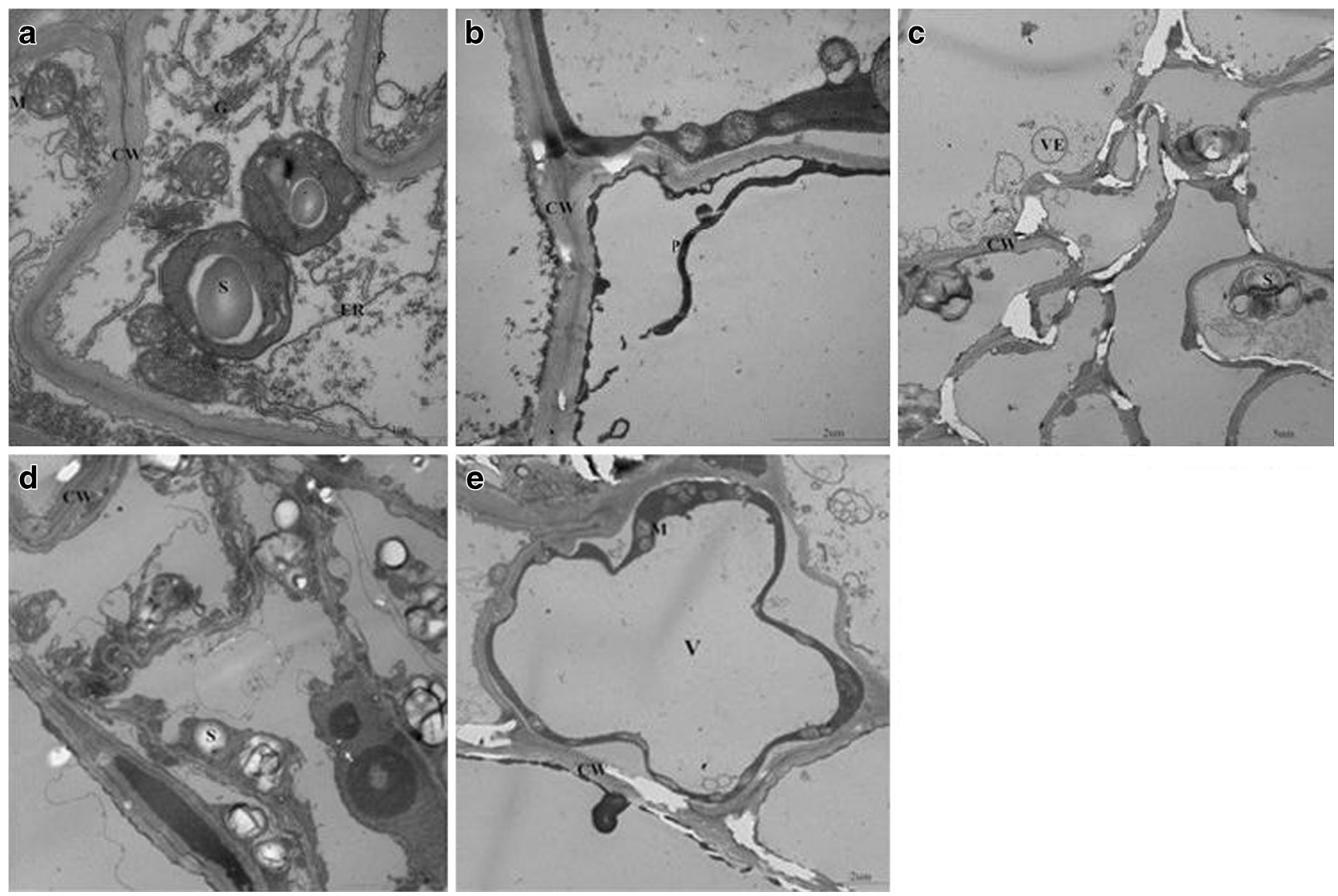

Fig. 6 Ultrastructural micrographs of cucumber root showed the typical cellular ultrastructure of root cells with or without DBP 
tolerant plants like $C$. sativus L. cv Jinyan No. 4 (Koca et al. 2007), Beta vulgaris (Gzik 1996) and Brassica juncea (Jain et al. 1991), sharp increases in proline levels were reported under the effect of salinity. The accumulation of this amino acid may be part of a general adaptation to adverse environmental conditions (Delauney and Verma 1993).

The roots ultrastructural study showed that the organelles were obviously affected. In the present study, we observed some organelles in cucumber roots showed apparent changes under the impact of DBP. Damage to plasma membrane and plasmolysis phenomenon might be because of the increased content of MDA and Pro. The increase of MDA content at all treatment levels might result in cellular injury which causes organelle damage (Forman et al. 2002; Lara-Nunez et al. 2006). Pro is thought to play a cardinal role as an osmoregulatory solute in plants subjected to hyperosmotic stress, primarily drought and soil salinity (Delauney and Verma 1993). The content of MDA and Pro was increased in this study which indicated that changes of MDA and Pro were the important reasons leading to the damage of plasma membrane and plasmolysis.

Mitochondrion is one of the important sources of $\mathrm{H}_{2} \mathrm{O}_{2}$ in plant cells (Hernandez et al. 2010; Rhoads et al. 2006). According to Yamane et al. (2012), $\mathrm{H}_{2} \mathrm{O}_{2}$ generated from the electron transfer chains damaged mitochondrial cristae under the influence of salinity. Similar findings were observed in root tip cells of soybean under $\mathrm{Al}$ stress (Yu et al. 2011). It was founds that the mitochondria in root tip cells were irregular in shape and swollen; the cristae system was a little bit distorted under Al stress. This variation was caused by the decline of CAT and POD activities. Plant cell vacuoles are one of the most variable multifunctional organelles. The vacuoles of root cells have storage functions (Zaalishvili et al. 2002). Enlargement of the vacuoles could be observed in this present work. The results obtained are in agreement with previous reports of Dauda et al. (2009), when exposing transgenic cotton to $\mathrm{Ca}$. Increase in the size of vacuoles might be helpful in preventing the circulation of DBP in the cytosol and forcing them into a limited area (Sanita and Gabbrielli 1999). Numerous starch grains were discovered in root cells. The concentration of these grains was possibly due to the root cells not adapting to DBP and therefore presenting the aging change. Santos et al. (2013) and Bouzon et al. (2012) also found this appearance when mesophyll cells were exposed to Cd.

In conclusion, C. sativus L. cv Jinyan No. 4 was found to be sensitive to DBP. DBP stress significantly affected enzyme activities, lipid peroxidation, and caused damage to root cells. Cucumber could defend lower-concentration DBP stress $\left(<50 \mathrm{mg} \mathrm{L}^{-1}\right)$ effectively by activating the antioxidant defense system. Compared to CAT, SOD, and POD exhibited a better defense mechanism against oxidative damage induced by DBP. This study would be helpful to understand the toxicity effect of PAEs to plant.
Acknowledgement This research was supported by the National High Technology Research and 863 Development Program of China (2012AA101405), Chang Jiang Scholar Candidates Program for Provincial Universities in Heilongiiang (2012CJHB001), University Science and Technology, Innovation Team Construction Projects of Heilongjiang Province (2013TD003), and Heilongjiang Postdoctoral Fund (LBHZ12037).

Open Access This article is distributed under the terms of the Creative Commons Attribution License which permits any use, distribution, and reproduction in any medium, provided the original author(s) and the source are credited.

\section{References}

Aebi H (1984) Catalase invitro. Methods Enzymol 105:121-126

Bai R, Ma FW, Liang D, Zhao X (2009) Phthalic acid induces oxidative stress and alters the activity of some antioxidant enzymes in roots of Malus prunifolia. J Chem Ecol 35:488-494

Bouzon ZL, Ferreira EC, dos Santos R, Scherner F, Horta PA, Maraschin M, Schmidt EC (2012) Influences of cadmium on fine structure and metabolism of Hypnea musciformis (Rhodophyta, Gigartinales) cultivated in vitro. Protoplasma 249:637-650

Chen Y, Wu C, Zhang H, Lin Q, Hong Y, Luo Y (2013) Empirical estimation of pollution load and contamination levels of phthalate esters in agricultural soils from plastic film mulching in China. Environ Earth Sci 70(1):239-247

Cho UH, Seo NH (2005) Oxidative stress in Arabidopsis thaliana exposed to cadmium is due to hydrogen peroxide accumulation. Plant Sci 168(1):113-120

Choudhary R, Saroha AE, Swarnkar PL (2012) Effect of abscisic acid and hydrogen peroxide on antioxidant enzymes in Syzygium cumini plant. J Food Sci Technol 49(5):649-652

Clausen PA, Hansen V, Gunnarsen L, Afshari A, Wolkoff P (2004) Emission of di-2-ethylhexylphthalate from PVC flooring into air and uptake in dust: emission and sorption experiments in FLEC and CLIMPAQ. Environ Sci Technol 38:2531-2537

Daud MK, Sun Y, Dawood M, Hayat Y, Variath MT, Wu Y-X, Raziuddin UM, Salahuddin UN, Zhu S (2009) Cadmium-induced functional and ultrastructural alterations in roots of two transgenic cotton cultivars. J Hazard Mater 161:463-473

Delauney AJ, Verma DPS (1993) Proline biosynthesis and osmoregulation in plants. Plant J 4(2):215-223

Demiral T, Türkan I (2005) Comparative lipid peroxidation, antioxidant defense systems and proline content in roots of two rice cultivars differing in salt tolerance. Environ Exp Bot 53:247-257

European Union (1993) Council Regulation (EEC), No. 793/93 of 23 March 1993 on the Evaluation and Control of the Risks of Existing Substances (OJ L 84, 5 April 1993), European Union, Brussels

Forman HJ, Torres M, Fukuto J (2002) Redox signaling. Mol Cell Biochem 234:49-62

Fromme H, Lahrz T, Piloty M, Gebhart H, Oddoy A, den Ru H (2004) Occurrence of phthalates and musk fragrances in indoor air and dust from apartments and kindergartens in Berlin (Germany). Indoor Air 14:188-195

Giannopolitis CN, Reis SK (1977) Superoxide dismutases: I. Occurrence in higher plants. Plant Physiol 59:309-314

Gomez-Hens A, Aguilar-Caballos MP (2003) Social and economic interest in the control of phthalic acid esters. Trends Anal Chem 22:847857

Gzik A (1996) Accumulation of proline and pattern of amino acids in sugar beet plants in response to osmotic, water and salt stress. Environ Exp Bot 36(1):29-38 
Hasan SA, Fariduddin Q, Ali B, Hayat S, Ahmad A (2009) Cadmium: toxicity and tolerance in plants. J Environ Biol 30:165-174

Hernandez M, Fernandez-Garcia N, Diaz-Vivancos P, Olmos E (2010) A different role for hydrogen peroxide and the antioxidative system under short and long salt stress in Brassica oleracea roots. J Exp Bot 61:521-535

Huang S, Li R, Zhang Z et al (2009) The genome of the cucumber, Cucumis sativus L. Nat Genet 41:1275-1281

Inoue $\mathrm{K}$, Kawaguchi M, Yamanaka R, Higuchi T, Ito R, Saito K, Nakazawa H (2005) Evaluation and analysis of exposure levels of di(2-ethylhexyl) phthalate from blood bags. Clin Chim Acta 358: $159-166$

Jain S, Nainawatee HS, Jain RK, Chowdhury JB (1991) Proline status of genetically stable salt-tolerant Brassica juncea $\mathrm{L}$. somaclones and their parent cv. 'Parkash'. Plant Cell Rep 9:684-687

Kang YS, Lee Y, Jung H, Jeon CO, Madsen EL, Park W (2007) Overexpressing antioxidant enzymes enhance snaphthalene biodegradation in Pseudomonas sp. strain As1. Microbiology 153:3246-3254

Koca H, Bor M, Ozdemir F, Turkan I (2007) The effect of salt stress on lipid peroxidation, antioxidative enzymes and proline content of sesame cultivars. Environ Exp Bot 60:344-351

Koch HM, Angerer J, Drexler H, Eckstein R, Weisbach V (2005) Di(2ethylhexyl)phthalate (DEHP) exposure of voluntary plasma and platelet donors. Int J Hyg Environ Health 208:489-498

Kong SF, Ji YQ, Liu LL, Chen L, Zhao XY, Wang JY, Bai ZP, Sun ZR (2012) Diversities of phthalate esters in suburban agricultural soils and wasteland soil appeared with urbanization in China. Environ Pollut 170:161-168

Kreiner M, Harvey LM, McNeil B (2002) Oxidative stress response of a recombinant Aspergillus niger to exogenous menadione and $\mathrm{H}_{2} \mathrm{O}_{2}$ addition. Enzym Microb Technol 30:346-353

Lara-Nunez A, Romero-Romero T, Ventura JL, Blancas V, Anaya AL, Cruz-Ortega R (2006) Allelochemical stress causes inhibition of growth and oxidative damage in Lycopersicon esculentum Mill. Plant Cell Environ 29:2009-2016

Li CL, Xu HM, Xu J, Chun XY, Ni DJ (2011) Effects of aluminum on ultrastructure and antioxidant activity in leaves of tea plant. Acta Physiol Plant 33:973-978

Li Y, Zhang XL, Yang YQ, Li B, Duan (2013) Soil cadmium toxicity and nitrogen deposition differently affect growth and physiology in Toxicodendron vernicifluum seedlings. Acta Physiol Plant 35(2): 529-540

Liang P, Zhang L, Peng L, Li Q, Zhao E (2010) Determination of phthalate esters in soil samples by microwave assisted extraction and high performance liquid chromatography. Bull Environ Contam Toxicol 85:147-151

Liu N, Xu G, Wu MH, He XX, Tang L, Shi WY, Wang L, Shao HY (2012b) Radical-induced destruction of diethyl phthalate in aqueous solution: kinetics, spectral properties, and degradation efficiencies studies. Res Chem Intermed:1-11

Michael PR, Adams WJ, Werner AE, Hicks O (1984) Surveillance of phthalate-esters in surface waters and sediments in the UnitedStates. Environ Toxicol Chem 3:377-389

Mishra S, Srivastava S, Tripathi RD, Govindarajan R, Kuriakose SV, Prasad MNV (2006a) Phytochelatin synthesis and response of antioxidants during cadmium stress in Bacopa monnieri L. Plant Physiol Biochem 44:25-37

Mishra S, Srivastavaa S, Tripathi RD, Govindarajan R, Kuriakose SV, Prasad MNV (2006b) Phytochelatin synthesis and response of antioxidants during cadmium stress in Bacopa monnieri L. Plant Physiol Biochem 44(1):25-37

Nel A, Xia T, Madler L, Li N (2006) Toxic potential of materials at the nanolevel. Science 311:622-627

Nielsen F, Mikkelsen BB, Nielsen JB, Andersen HR, Grandjean P (1997) Plasma malondialdehyde as biomarker for oxidative stress: reference interval and effects of life-style factors. Clin Chem 43:1209-1214
Niki E (2008) Lipid peroxidation products as oxidative stress biomarkers. Biofactors 34:171-180

Odjegba VJ, Fasidi IO (2007) Changes in antioxidant enzyme activities in Eichhornia crassipes (Pontederiaceae) and Pistia stratiotes (Araceae) under heavy metal stress. Rev Biol Trop 55:815-823

Pinhero RG, Rao MV, Paliyath G, Murr DP, Fletcher RA (1997) Changes in activities of antioxidant enzymes and their relationship to genetic and paclobutrazol-induced chilling tolerance of maize seedlings. Plant Physiol 114:695-704

Pollard A, Wyn Jones RG (1979) Enzyme activities in concentrated solutions of glycinebetaine and other solutes. Planta 144:291-298

Qu BC, Zhao HX, Zhou JT (2010) Toxic effects of perfluorooctane sulfonate (PFOS) on wheat (Triticum aestivum L.) plant. Chemosphere 79:555-560

Qureshi MI, Abdin MZ, Qadir S, Iqbal M (2007) Lead induced oxidative stress and metabolic alterations in Cassia angustifolia Vahl. Biol Plant 51:121-128

Radotic K, Ducic T, Mutavdzic D (2000) Changes in peroxidase activity and isoenzymes in spruce needles after exposure to different concentrations of cadmium. Environ Exp Bot 44:105-113

Rhoads DM, Umbach AL, Subbaiah CC, Siedow JN (2006) Mitochondrial reactive oxygen species. Contribution to oxidative stress and interorganellar signaling. Plant Physiol 141:357-366

Russo MV, Notardonato I, Cinelli G, Avino P (2012) Evaluation of an analytical method for determining phthalate esters in wine samples by solid-phase extraction and gas chromatography coupled with iontrap mass spectrometer detector. Anal Bioanal Chem 402:13731381

Sanchez-Moreiras AM, Reigosa MJ (2005) Whole plant response of lettuce after root exposure to BOA (2(3H)-benzoxazolinone). J Chem Ecol 31:2689-2703

Sanita LT, Gabbrielli R (1999) Response to cadmium in higher plants. Environ Exp Bot 41:105-130

Santos RW, Schmidt EC, Bouzon ZL (2013) Changes in ultrastructure and cytochemistry of the agarophyte Gracilaria domingensis (Rhodophyta, Gracilariales) treated with cadmium. Protoplasma 250:297-305

Sathyanarayana S, Karr CJ, Lozano P, Brown E, Calafat AM, Liu F, Swan SH (2008) Baby care products: possible sources of infant phthalate exposure. Pediatrics 121:260-268

Shevyakova NI, Bakulina EA, Kuznetsov VV (2009) Proline antioxidant role in the common ice plant subjected to salinity and paraquat treatment inducing oxidative stress. Russ J Plant Physiol 56(5): 663-669

US EPA (1991) National Primary Drinking Water Regulations, Federal Register, 40 CFR, Part 141. US Environmental Protection Agency, Washington, DC, Chapter I

Valko M, Rhodes CJ, Moncol J, Izakovic M, Mazur M (2006) Free radicals, metals and antioxidants in oxidative stress-induced cancer. Chem Biol Interact 160:1-40

Wang JL, Liu P, Qian Y (1995) Microbial degradation of di- $n$-butyl phthalate. Chemosphere 31:4051-4056

Wang W, Zhang Y, Wang S, Fan CQ, Xu H (2012) Distributions of phthalic esters carried by total suspended particulates in Nanjing, China. Environ Monit Assess 184:6789-6798

Wang J, Lou YM, Ying Teng Y, Ma WT, Christie P, Li ZG (2013) Soil contamination by phthalate esters in Chinese intensive vegetable production systems with different modes of use of plastic film. Environ Pollut 180:265-273

Waters LJ, Leharne SA, Mitchell JC, Hanrahan JP (2007) Determination of micelle/water partition coefficients and associated thermodynamic data for dialkyl phthalate esters. J Therm Anal Calorim 90:283288

Wen YZ, Chen H, Shen CS, Zhao MR, Liu WP (2011) Enantioselectivity tuning of chiral herbicide dichlorprop by copper: roles of reactive oxygen species. Environ Sci Technol 45:4778-4784 
Wensing M, Uhde E, Salthammer T (2005) Plastics additives in the indoor environment-flame retardants and plasticizers. Sci Total Environ 339:19-40

Xu G, Li FS, Wang QH (2008) Occurrence and degradation characteristics of dibutyl phthalate (DBP) and di-(2-ethylhexyl) phthalate (DEHP) in typical agricultural soils of China. Sci Total Environ 393:333-340

Yamane K, Taniguchi M, Miyake H (2012) Salinity-induced subcellular accumulation of $\mathrm{H}_{2} \mathrm{O}_{2}$ in leaves of rice. Protoplasma 249:301-308

Yu HN, Liu P, Wang ZY, Chen WR, Xu GD (2011) The effect of aluminum treatments on the root growth and cell ultrastructure of two soybean genotypes. Crop Prot 30:323-328

Zaalishvili G, Sadunishvili T, Scalla R, Laurent F, Kvesitadze G (2002) Electron microscopic investigation of nitrobenzene distribution and effect on plant root tip cells ultrastructure. Ecotoxicol Environ Saf $52: 190-197$
Zeng F, Cui KY, Xie ZY, Wu LN, Luo DL, Chen LX, Lin YJ, Liu M, Sun GX (2009) Distribution of phthalate esters in urban soils of subtropical city, Guangzhou. J Hazard Mater 164:1171-1178

Zhang JF, Shen H, Xu TL et al (2003) Effects of long-term exposure of low-level diesel oil on the antioxidant defense system of fish [J]. Bull Environ Contam Toxicol 71(2): 234-239

Zhang SS, Zhang HM, Qin R, Jiang WS, Liu DH (2009) Cadmium induction of lipid peroxidation and effects on root tip cells and antioxidant enzyme activities in Vicia faba L. Ecotoxicology 18: 814-823

Zhang Y, Wang L, Du N, Ma GP, Yang AM, Zhang H, Wang ZG (2014) Effects of diethylphthalate and di-(2-ethyl)hexylphthalate on the physiology and ultrastructure of cucumber seedlings. Environ Sci Pollut Res 21(2):1020-1028 